\title{
Effect of Nitrogen Fertilization on the Density of the Corn Leafhopper and Its Impact on Both Disease Incidence and Natural Parasitism
}

Eduardo Gabriel Virla ( $\nabla$ egvirla@lillo.org.ar)

Fundacion Miguel Lillo https://orcid.org/0000-0002-9512-4254

Erica B. Luft Albarracín

CONICET: Consejo Nacional de Investigaciones Cientificas y Tecnicas

Cecilia Diaz

Universidad Nacional de Tucumán: Universidad Nacional de Tucuman

Guido A. Van Nieuwenhove

Fundación Miguel Lillo: Fundacion Miguel Lillo

Franco D. Fernández

INTA: Instituto Nacional de Tecnologia Agropecuaria

María V. Coll Aráoz

CONICET: Consejo Nacional de Investigaciones Cientificas y Tecnicas

Nicolás Melchert

CONICET: Consejo Nacional de Investigaciones Cientificas y Tecnicas

Luis R. Conci

INTA: Instituto Nacional de Tecnologia Agropecuaria

María P. Giménez Pecci

INTA: Instituto Nacional de Tecnologia Agropecuaria

Research Article

Keywords: Bottom-up control, corn stunt disease, Dalbulus maidis, maize, Spiroplasma kunkelii, vector

Posted Date: September 8th, 2021

DOI: https://doi.org/10.21203/rs.3.rs-840055/v1

License: (c) (i) This work is licensed under a Creative Commons Attribution 4.0 International License. Read Full License 


\section{Abstract}

The corn leafhopper Dalbulus maidis (Hemiptera: Cicadellidae) is a specialist herbivore that attacks maize in the tropical and subtropical regions of the Americas. It is vector of three relevant plant pathogens being responsible for severe yield losses. Modern agriculture is dependent on the addition of fertilizers, especially nitrogen, which may influence the nutritional quality of the plants possibly with a subsequent increment of herbivorous insect populations. Through a field experiment, using a randomized design with four treatments with different levels of fertilization, we evaluated the effects of nitrogen fertilization in corn on the population levels of the vector $D$. maidis, on the incidence of the diseases transmitted by it, and on the levels of parasitism of the vectors' eggs. The amount of nitrogen fertilizer used significantly influenced the density of the corn leafhopper and the parasitism by egg parasitoids, but not the incidence of the diseases transmitted by it. Two weeks after fertilization, the vector density was significantly higher in the highly fertilized treatment. The disease incidence was not directly linked with the level of fertilization, however, the symptoms of the diseases were much less evident in plants that received higher fertilization. Parasitism levels by egg parasitoids increased accordingly to the level of $D$. maidis populations.

\section{Key Message}

1) Nitrogen fertilization significantly influenced the density of the corn leafhopper and the parasitism by egg parasitoids. 2) Corn stunting disease incidence was not directly linked with the level of fertilization, however, the symptoms of the diseases were much less evident in plants that received higher fertilization.

\section{Introduction}

Fertilization has been, along with plant breeding, one of the most powerful tools to increase grain yield and has contributed to the doubling of cereal production in the past 40 years (Tilman et al. 2002). Intensive high-yield agriculture is dependent on fertilizer amendments, especially nitrogen fertilizers (Tilman et al. 2002). Nitrogen ( $\mathrm{N}$ ) is a macronutrient in plants, but its excess has diverse negative environmental effects. Concerning crop pests, fertilization may influence the plant's nutritional quality, increasing the population of herbivorous insects (Waring and Cobb 1992; Cook and Denno 1994) and could also affect the recruitment of their natural enemies (Chen et al. 2010; Fallahpour et al. 2019; Shehzad et al. 2020). In the current scenario, the challenge is to increase yields while reducing the environmental impacts (Foley et al. 2011). In South America, extensive agriculture, and particularly corn production, has adopted a high level of technification incorporating fertilization as an almost unavoidable input. This is especially verified in Argentina, where fertilizer amendments increased from about 300,000 to 4,305,000 tons in the period between 1990 and 2018 (Fertilizar 2020a), and 814,743 tons of N fertilizers were used for corn cultivation during the 2017-18 growing season (Fertilizar 2020b).

Among the limiting factors of maize production, hoppers (Hemiptera: Auchenorrhyncha) are notorious because they can cause direct damages (feeding and oviposition) and indirect effects due to their ability to transmit various pathogens (viruses, phytoplasmas, spiroplasmas, and classical bacteria) (Weintraub and Beanland 2006). Direct damages result in tissue necrosis with diverse degrees of severity and physiological alterations (i.e. water stress) (Virla et al. 2021). These characteristics are aggravated by their high reproductive potential, short life cycle, great dispersal, and adaptability (Luft Albarracín et al. 2009).

One of the most important corn pests in the tropical and subtropical Americas is the corn leafhopper, Dalbulus maidis De Long (Hemiptera: Cicadellidae) because it is an efficient vector of three plant diseases: "corn stunt" (CSS, Spiroplasma kunkelii Whitcom et al.; = Spiroplasma phoeniceum Saillard according with GBIF 2021 catalogue), "maize bushy stunt" (MBSP, Candidatus Phytoplasma asteris), and "corn streak or maize rayado fino" (MRFV, Maize rayado fino virus) (Virla et al. 2010; Santana et al. 2019). The vector shows a broad distribution throughout the Americas: it has been detected from Southeastern and Southwestern USA to Argentina (Santana et al. 2019). In Northern Argentina, it is the most common leafhopper feeding on corn (Luft Albarracín et al. 2009). CSS, MBSP, and MRFV make up the pathosystem known as "corn stunting disease" or "achaparramiento" and may occur in the same areas or the same maize plant together; in South America S. kunkelii is the most relevant due to its high incidence, followed by MBSP and the less frequent MRFV (Virla et al. 2004; Giménez Pecci et al. 2017; Santana et al. 2019). The typical symptoms of $S$. kunkelii are chlorotic stripes running from the base of the leaf blades and extending towards the apex; stunted growth of the plant due to the progressive shortening of the upper internodes, and the proliferation of ears in different nodes, so that grain yield is markedly reduced, even to zero if the plants are severely attacked (Virla et al. 2004; Carpane et al. 2006). S. kunkelii causes decreased absorption of $\mathrm{N}, \mathrm{P}, \mathrm{K}, \mathrm{Ca}, \mathrm{Mg}, \mathrm{S}, \mathrm{Zn}$ and other alterations in the corn plants physiology, like limited water retention in tissues (de Oliveira et al. 2002, 2005). Depending on the corn genotype and the weather, MBSP symptoms include reddening and shortening of the internodes. The symptomatic plants also present tearing, twisting, and deformation of leaves and numerous ears and tillers arising from the leaf axils and the plant base. MBSP development is favored by high temperatures. Outbreaks of the corn stunting disease have been reported in countries of Central and South America, like Nicaragua and Brazil (de Oliveira et al. 2018).

It is known that nitrogen fertilization can have significant effects on sap-feeder insects, like several aphids and leafhoppers species, leading to higher population densities (Prestidge 1982; Douglas 2006). The effect of maize crop fertilization in D. maidis populations was addressed twice, showing inconsistent findings: Power (1989) stated that nitrogen fertilization (urea 45\%) does not affect the abundance of the vector nor the incidence of the corn stunt disease while, on the other hand, Schetino Bastos et al. (2007) reported that the presence of $D$. maidis increases as nitrogen, sulfur, calcium and copper concentration increases in the cornfield.

The corn leafhopper has a rich natural enemy complex, being the egg parasitoids guild the most relevant according to the species richness. In Argentina, the eggs of the vector are parasitized by 16 different species, including Mymaridae, Trichogrammatidae, Aphelinidae, and Eulophidae (Hymenoptera: Chalcidoidea) (Luft Albarracín et al. 2017). It is widely recognized that plant quality can affect both the herbivore abundance and the tri-trophic levels (Tariq et al. 2012; Shehzad et al. 2020). In particular, parasitoids respond to volatile cues that indicate the presence of hosts (Turlings et al. 1990; Coll Aráoz et al. 2020). These olfactory cues could be signals from the host itself (kairomones), from the host plant (synomones), or could be a combination of both (Vinson 
1999). Changes in the nutritional status of the plants can alter the volatile and non-volatile semiochemicals that guide the parasitoids and/or finally determine the hosts' acceptance (Blande et al. 2007).

Knowledge of the fertilization effects on the crops is crucial for developing effective management strategies (Han et al. 2019). So, taking into account the importance of $D$. maidis and corn stunting disease for corn productivity in tropical and subtropical Americas, the increase in the use of $\mathrm{N}$ fertilizers, and the divergent results obtained in previous studies regarding this issue with the vector, this contribution aimed to evaluate the effect of $\mathrm{N}$ fertilization on a) population levels of $D$. maidis throughout the vegetative stage of the crop, b) the final incidence of $S$. kunkelii and MBSP, and c) the bottom-up control of the vector by egg parasitoids. We postulate the following predictions: 1) the populations of the vector will be higher in the most fertilized treatment, 2) in concomitance with the higher populations of the vector, the incidence of the diseases will be higher in the more fertilized treatments and, 3) egg parasitism rates will be higher in the treatment with higher densities of the vector (density-dependent).

\section{Materials And Methods}

A field experiment was carried out under natural rainfall in the Facultad de Agronomía and Zootecnia, Universidad de Tucumán, Argentina, located at El Manantial (S $26^{\circ} 4950.2, W 65^{\circ} 1659.4$, elevation: $495 \mathrm{~m}$ ). El Manantial is in the foothills of San Javier Mountains, covered by the subtropical Yungas rainforest. The rainfall during the experiment (December 26, 2018 - March 28,2019 ) was $733.2 \mathrm{~mm}$, with 55 rainy days. The average temperature was $23.6{ }^{\circ} \mathrm{C}$ with a mean thermal amplitude of $10.2^{\circ} \mathrm{C}$, and the relative humidity average ascends to $81 \%$ (EEAOC 2021).

\section{Assay}

The experiment was a randomized complete design with four treatments and five replications. Each micro-plot [6 rows (spaced $0.50 \mathrm{~m}$ apart) $\mathrm{x} 7 \mathrm{~meters} \mathrm{long}$, separated from each other by corridors 2.5 meters wide] was sown manually with 168 seeds of Syn 126 Viptera $3 \AA$ (Syngenta) (sowing density 78,000 - 80,000 plants/ha). It is a subtropical transgenic hybrid of a short cycle. The sowing date was December 26, 2018, optimal time for the region, and the seeds had an insecticidal treatment (Cruiser ${ }^{\circledR}, 35 \mathrm{~g}$ Tiametoxam) provided by the supplying company, with a coverage of up to 15 days after sowing. Subsequently, no agrochemicals were applied, except the fertilization planned for each treatment.

When the maize plants were in vegetative stage $V_{3}$ (third leaf vegetative stage, 16 days after seedtime; January 11, 2019), we applied four levels of granulated and solid $\mathrm{N}$ fertilizer YaraBela ${ }^{\circledR}$ Nitrodoble (Yara) [ammoniacal nitrogen-nitric (27\%), nitric nitrogen (13.6\%), ammoniacal nitrogen (13.4\%), calcium (5\%) and magnesium (2.3\%)]. Treatments were: N0 = non-fertilized (control); N100 = fertilizer doses of $100 \mathrm{~kg}^{*} \mathrm{ha}^{-1}$ (low fertilization); N200 = fertilizer doses of 200 $\mathrm{kg}^{\star} \mathrm{ha}^{-1}$ (normal fertilization); N300 = fertilizer doses of $300 \mathrm{~kg}^{\star} \mathrm{ha}^{-1}$ (high fertilization). A dose of $200 \mathrm{~kg}^{\star}$ ha ${ }^{-1}$ is recommended by the supplier to farmers in the region.

In the area, the soil is a typical fine Argiudoll, a deep loess soil (Pereyra and Fernández 2018). Before conducting the experiment, physical and chemical analysis was carried out on the soil. The soil (N0) was a franc-silty textural class, with $2.71 \%$ of organic material, pH $5.93,0.160 \%$ of total nitrogen, $55.7 \mathrm{ppm}$ of $\mathrm{NO}_{3}\left(32.3 \mathrm{KgN}^{*} \mathrm{ha}^{-1}\right), 7.7 \mathrm{ppm}$ of phosphorus, $1.17 \mathrm{me} / 100 \mathrm{~g}$ of potassium, and $0.53 \mathrm{dS} / \mathrm{m}$ of salinity by the electrical conductivity of the saturation extract.

To check the effectiveness of the nitrogen treatment a phenological evaluation of the corn crop, 54 days after seeding (February 18, 2019), was performed, including leaf relative chlorophyll content using an N-TESTER ${ }^{\text {TM }}$ (Yara) device (Table 1). Data were obtained measuring 30 plants of each micro-plot.

\section{Vector population sampling}

The density of the vector (adults) was calculated based on the exhaustive (non-extractive) review of 3 groups of 20 plants each, taken at random, from each replicate of the treatments (Luft Albarracín et al. 2009). We searched for corn leafhoppers resting or feeding on the corn plants. Sampling was carried out weekly, from the first fully expanded leaf stage to $V_{7-8}$ (seventh-eighth leaf vegetative stage, 42 days after seedtime) according to the technique by $V_{i r l a}$ et al. (2010). The density was measured based on the average number of insects per plant, recorded on each sampling date. On the fertilization day, the mean density of the vector was 0.0175 adults/plant.

The reason for monitoring the vector from the first leaf to $V_{7-8}$ stages is because the early phenological stages of corn are the most susceptible to the acquisition of CSS (Hruska and Gómez Peralta 1997), and in further growth stages, the canopy is so developed that it is impossible to continue with accurate monitoring of the vector.

\section{Spiroplasma kunkelii and MBSP detection and incidence calculation}

A visual evaluation of the typical symptoms of "corn stunting disease" was performed on the same plants surveyed for vector abundance to estimate the \% of symptomatic plants in each treatment.

At milk grain stage (R3, 89 days after sowing), the second leaf below the tassel was collected at random from 40 plants from each treatment for $S$. kunkelii and MBSP detection (Virla et al. 2004). Leaves were taken to the laboratory and kept at $4{ }^{\circ} \mathrm{C}$ until they were tested for the presence of $S$. kunkelii by doubleantibody sandwich enzyme-linked immunosorbent assay using locally developed antisera (Giménez Pecci et al. 2009). MBSP phytoplasm detection was acceded by PCR using the universal primer pairs P1-P7 (1.8 kb) (Deng and Hiruki, 1991) and R16F2n-R16R2 (1.2 kb) (Gundersen and Lee 1996), in direct and nested reactions respectively, as previously stated by Galdeano et al. (2013). Reactions were performed in a thermal cycler (TRIO-Thermoblock, Biometra) in $40 \mu \mathrm{L}$ reaction solution containing $50 \mathrm{ng}$ of template DNA, $0.4 \mathrm{mM}$ each primer, $100 \mathrm{mM}$ dNTPs, 1 U GoTaq DNA Polymerase (Promega). In nested reaction, 1

Loading [MathJax]/jax/output/CommonHTML/jax.js 
$\mu \mathrm{L}$ of 1:25 fold P1/P7 PCR product dilution was employed. Total nucleic acid was purified using the Doyle and Doyle (1990) protocol. The quality and quantity of DNA were accessed by agarose gel electrophoresis and by spectrophotometry (NanoDrop $\left.{ }^{\circledR}, \mathrm{NANO}-1000\right)$.

Spiroplasma kunkelii and MBSP incidence was estimated as the percentage of plants with a positive reaction. The tests for MRFV were not performed because this pathogen has been registered sporadically in Argentina (Giménez Pecci et al. 2017) and no symptoms were observed to indicate its presence.

\section{Bottom-up control by egg parasitoids}

The percentage of parasitism of the vectors' eggs was measured through the exposure of sentinel eggs. Six to ten females of $D$. maidis from a colony maintained at the laboratory were placed for oviposition in PET (polyethylene-terephthalate) cylindrical cages ( $35 \mathrm{~cm}$ high $\times 18 \mathrm{~cm}$ diameter) enclosing a distal part of the leaves of maize plants belonging to each treatment to obtain the sentinel eggs (Luft Albarracín et al. 2017). Cages were placed on the basal leaves from two plants in each micro-plot (a total of 10 plants per treatment). The plants used for the sentinel eggs were selected at random, but always 1.5 meters from the edge, inside the micro-plot. The cages with the females were kept enclosing the leaves for 3 days (from February $8^{\text {th }}$ to $11^{\text {th }}$ ) and then were removed along with $D$. maidis females in order to expose the eggs to natural parasitism, from February $11^{\text {th }}$ to $18^{\text {th }}$. After that period, the leaves containing exposed eggs were cut from the plant and transferred to Petri dishes containing wet tissue paper at the bottom, which were then covered with clear plastic wrap to avoid desiccation. The total number of eggs and parasitized ones were checked 10 days after by subsequent dissections. Eggs developing eyespots were considered as "unparasitized" meanwhile, those that changed to brownish, reddish, or black were considered as "parasitized" (Virla et al. 2005). A total of 770 eggs were exposed: 221 for N0 (control), 118 for N100, 174 for N200, and 187 for N300.

\section{Statistical Analysis}

Dalbulus maidis adult field density was subjected to a generalized mixed linear model with a normal distribution and log link function. Treatment was included as a fixed variable while replicates, i.e. sampling day, were included as a random variable.

To estimate the rate of growth of $D$. maidis adult population and its relationship with the stage of development of the crop for each treatment simple linear regression were performed. Moreover, linear regressions to assess the relationship between the \% of symptomatic plants for the "corn stunting" disease and the age of the crop were made.

The natural parasitism of $D$. maidis' eggs were subjected to a generalized linear model with a binomial distribution and a logit link function at $\mathrm{a}=0.05$. Followed to the analyses, a LSD test for means segregation was used. Data are presented as mean \pm SEM. In addition, a simple linear regression to elucidate the relationship between parasitism rate and adult field density of $D$. maidis recorded for each treatment when assessing natural parasitism (i.e. 42 days after sowing) were performed. Statistical analyses were performed using IBM SPSS ${ }^{\circledR}$.

\section{Results}

\section{Vector populations}

The GLMM shows that $D$. maidis adult density was significantly affected by fertilizer concentration $(F=94.31, \mathrm{df}: 3-23, p<0.01)$. Adult field density of $D$. maidis increased significantly as the fertilizer concentration increased (Fig. 1). Overall means of adult densities registered for the different treatments were significantly different among them (LSD test, $p<0.05$ ), $0.121 \pm 0.0022,0.192 \pm 0.0015,0.265 \pm 0.0026$, and $0.279 \pm 0.0022$ for N0, N100, N200, and N300 respectively. 42 days after sowing, an average density of 0.067 adults/plant was recorded in the control treatment while in the highly fertilized treatment the mean density was 5.5 fold higher, 0.373 adults/plant (Fig. 1; Table 1).

Linear regression showed that just the addition of fertilizer significantly increased $D$. maidis densities. In this context, the rates of growth of $D$. maidis adults were 13, 9, and 6 fold higher, for N300, N200, and N100 treatments respectively, regarding control treatment (Fig. 1).

\section{Incidence of the diseases}

On day 54 after sowing, the first symptomatic plants for all treatments were detected. Moreover, the percentage of symptomatic plants assessed visually decreased as the fertilization level increased (Fig. 1). 89 days after sowing and by analytical determinations, the most affected plants were those from the control treatment and those from the N300 treatment, although symptoms were masked in the latter (Table 2). The visual evaluation of the symptoms of the diseases transmitted by the corn leafhopper (S. kunkelii and MBSP) underestimated the real number of affected plants (Table 2). This was particularly notorious with the MBSP symptoms in the highly fertilized treatments. The laboratory analysis (serological and PCR) confirmed that there was no direct relation between the incidence of pathogens and the level of crop fertilization (Table 2). All the samples that showed reddening of the leaves had the presence of the pathogen MBSP. Many plants had a double infection, which is almost impossible to recognize in the field.

\section{Bottom-up control by egg parasitoids within the treatments}

The analysis showed that parasitism rates were significantly affected by fertilization treatment $\left(c^{2}=56.50, d f: 3, p<0.01\right)$. The lower parasitism rates were observed in control and N100 treatments $(0.163 \pm 0.025$ and $0.165 \pm 0.027$ respectively), which significantly differ from conventional (N200) and higher fertilization treatments $(0.275 \pm 0.034$ and $0.465 \pm 0.036$, respectively). In addition, a highly significant positive correlation was observed between parasitism rate and $D$. maidis' adult density/corn plant ( $\mathrm{F}=14.11$, df:1-39; $\mathrm{p}<0.01)$ (Fig. 2$)$. An increase of 0.1 adults of $D$. maidis/corn plant leads to an increase in the rate of parasitism close to $11 \%$ (Fig. 2). 


\section{Discussion}

In this study, the effects of nitrogen fertilization in maize on $D$. maidis density, the incidence of the diseases transmitted by it, and the percentage of parasitism of its eggs were explored. As expected, the increase in $\mathrm{N}$ content in plants, caused an increase in the density of the vector, and consequently higher parasitism rates. However, we did not record a direct relationship in the incidence of diseases.

\section{Vector populations}

The density of the vector increased in the fertilized plots relative to the control plots. But the differences were clearly verified two weeks after crop fertilization, with significantly higher densities in the highly fertilized treatment when compared to the N0 (control) and N100 treatments (Fig. 1), presumably because of the effect of the fertilizer on plant quality. On a previous study, Power (1989) stated that nitrogen fertilization affected maize growth but had no impact on $D$. maidis abundance, although later Schetino Bastos et al. (2007) reported a direct relationship between the nitrogen content in corn leaves and the number of nymphs and adults of the corn leafhopper. Plants with a higher level of fertilization are more palatable to sap-sucking insects (Bernays and Chapman 1994), because of the increment of nitrate and soluble amino acids in the phloem sap (Ponder et al. 2000; Douglas 2006). Auchenorrhyncha insects survive better, develop faster, molt into larger adults, and are more fecund if they develop on nitrogen-rich host plants (Rossi et al. 1991; Cook and Denno, 1994). Considering that the life cycle of the vector (egg to egg) is 42 days at $25^{\circ} \mathrm{C}$ (Van Nieuwenhove et al. 2016) and that the average temperature recorded during our experiment was similar, we estimate that most of the recorded adults during our experiment were colonizing migrants. $D$. maidis adults have high mobility (Castro et al. 1992; Oliveira et al. 2002) and can detect through visual and/or olfactory cues which plants offer a better nutritional status (i.e. where the leaves chlorophyll content is higher) (Table 1). We do not know yet how adults are oriented towards the most palatable plants in the field; whether they orient mostly by visual stimuli, considering the leaves color or the biomass amount (Todd et al. 1990), or olfactory cues that allow discrimination between more adequate hosts from a nutritional point of view (Coll Aráoz et al. 2019). Rossi et al. (1991) stated that the leafhopper Carneocephala floridana (Hem.: Cicadellidae) preferred plants with higher nitrogen content, and those individuals that reached them had a significant competitive advantage due to an increase in body size and fertility. Also, Cook and Denno (1994) described that macropterous of the planthopper Prokelisia marginata (Hem.: Delphacidae) moved from nutritionally inferior host plants to nitrogen-enriched ones.

\section{Incidence of the diseases}

Power (1989) affirmed that nitrogen fertilization did not impact CSS incidence. In accordance, our study demonstrated that the incidences of CSS and MBSP were not directly linked with the level of $\mathrm{N}$ fertilization, however, the symptoms of the diseases were much less evident in plants that received higher fertilization (Table 2). It is well known that the symptomatology caused by $S$. kunkelli and MBSP depends on many factors, including germplasm, climatic factors, and fundamentally the phenological stage of the corn plant at the time of infection, and perhaps also the MBSP isolate (Carpane et al. 2006; de Oliveira et al. 2018). Infected plants in the early stages show the highest levels of symptomatology (Hruska and Gómez Peralta, 1997). We assumed that infective $D$. maidis adults similarly colonized the plots, since the latter were randomly distributed, therefore the inoculum pressure would have been similar at the beginning of the assay in every plot. Castro et al. (1992) evaluated the movement of D. maidis and proved that the flight activity depends mostly on the size of the field and not on the sown density of maize plants. It was expected that the incidence of the diseases would be higher in the treatments with a larger population of vectors; however, there was no clear relation between vector densities and the occurrence of disease. This may be due to the high mobility of the corn leafhopper and that infective adults could easily move from one treatment to another during the early stages of the culture, establishing themselves in the most fertilized treatment after $V_{5-6}$ (about 15 days after the fertilizer application) (Fig. 1), coinciding with the period of accumulation of dry matter by the plants. In contrast to our results, Castro et al. (1992) while studying the influence of maize sown density on the incidence of the "corn stunting" disease, found a lower percentage of infection in plots with a higher density compared to those with a lower density, as a result of fewer vectors per plant in the former. The use of nutrients by the plant and the consequent vegetative storage is well represented by a logistic-type curve, where three sub-periods are clearly distinguished: between the emergence and the beginning of the stem lengthening, the dry matter accumulates slowly, due to the weak growth of the vegetative organs, such as leaves and stems, but in the second stage a strong increase is verified reaching the maximum value; finally, coinciding with physiological maturation, a slight decrease in dry matter occurs due to foliar senescence (Evans 1972). The relationship between the level of $\mathrm{N}$ soil fertilization and the $\mathrm{N}$ uptake dynamics and use efficiency largely depends on various aspects such as soil, germplasm, planting density, etc. (Swank et al. 1982; Ciampitti and Vyn 2011).

\section{Bottom-up control by egg parasitoids within the treatments}

The nutritional status of plants can affect the foraging behavior of natural enemies and their effectiveness, leading to the decrease of the herbivore populations (Denno et al. 2003; Aqueel and Leather 2012; Han et al. 2019). According to our predictions, the treatments with the highest levels of fertilization, had the highest levels of parasitism. D. maidis eggs were 2.85 times more parasitized in the treatment with a higher level of fertilization than in the control. Several investigations showed that the supply of nitrogen to plants increases the parasitism rate for several species of Lepidoptera and aphids (Jansson et al. 1991; Kalule and Wright 2002; Staley et al. 2011). Moon et al. (2000) stated that Anagrus sp. nr armatus (Hymenoptera: Mymaridae) attacked significantly more eggs of Pissonotus quadripustulatus (Hemiptera: Delphacidae) on fertilized plants compared to those on unfertilized plants and they attributed the increase in the levels of parasitism to the changes in the morphology of the host plant induced by fertilization. Nitrogen fertilization impacts the nutritional value of plants, and thus triggers bottom-up effects in the third trophic level, due to better quality or larger size of the herbivores that feed on fertilized plants (Vinson 1998; Pérez-Contreras and Soler 2004). On the other hand, the lower availability of nitrogen can lead to an increase in plant defensive compounds (Chen et al. 2008), and their negative effects can extend to herbivores and higher trophic levels (Turlings and Benrey 1998).

We found a positive correlation between parasitism rates and host density. Optimal foraging theory suggests that parasitoids can maximize their parasitism rate by aggregating in high-density patches of hosts leading to a decrease in host search times by females or costs of time spent rejecting already-parasitized Loading [MathJax]/jax/output/CommonHTML/jax.js d 1977; Walde and Murdoch 1988). In a previous review on this subject, Gunton and Pöyry (2016) stated that in 
most cases there is a positive association between host density and parasitism, which is in line with our findings. They also found that negative correlations generally occur when either the host or the parasitoid species were exotic (i.e. lack of specificity), in the orders Lepidoptera or Diptera, when the parasitoid was larger, or when the study was conducted at a finer grain size (i.e. the area over which each datum for host density is measured). A strong positive densitydependent relationship between D. maidis and its egg parasitoids community has been reported (Moya-Raygoza 2020). A recent contribution tested the foraging behavior of D. maidis and its egg parasitoid Anagrus virlai (Hymenoptera: Mymaridae), comparing plants previously affected by conspecific herbivory and with no previous contact with the herbivores (Coll Aráoz et al. 2020); corn leafhopper females were able to detect and significantly preferred healthy seedlings of a corn landrace over the attacked ones and the egg parasitoid wasp was able to detect the attacked plants. The landrace tested released allomones that avoided colonization of more individuals from the pest and also attracted parasitoids, that where not attracted toward maize hybrids also assayed in the same study. The increase in parasitism registered in the treatment with higher fertilization, in our field experiment could be mediated by the volatiles released by the plants.

\section{Implications}

Our study demonstrated that two weeks after nitrogen fertilization, when the nutritional status of the plant improves, the populations of $D$. maidis increase accordingly to the levels of fertilization, as well as the parasitism levels of their eggs. Although we have not found a direct relationship between the increase in fertilization, the density of the vector, and the incidence of CSS and MBSP, we were able to verify that the plants that received the highest amount of nitrogen showed much fewer symptoms than those without fertilization. Further studies should be carried out to elucidate if the evident decrease in CSS and MBSP symptoms corresponded to improvements in the physiological state of the plants that allowed them to better withstand the diseases. The information obtained here is useful at the time of diagramming mitigation strategies for $D$. maidis populations and the incidence of diseases transmitted by them.

\section{Declarations}

Funding: This research was partially supported by ANPCyT PICT 2015-1147 and PIP CONICET nº 0222.

Conflicts of interest: The authors declare that they do not have any conflict of interest associated with this work.

Availability of data and material: Raw and derived data supporting the findings of this study are available from the corresponding author [EGV] on request.

Code availability: For the present study, no new software or algorithms were developed.

Authors' contributions: EGV and EBLA conceived and designed the study. The research and analysis were performed by EGV, EBLA, GAVN and MVCA with input from CD, FDF, NAM, LRC, and MPGP. All authors contributed to the interpretation of results and writing the manuscript.

Ethical approval: This article does not contain any studies with human participants and/or animals (other than insects) performed by any of the authors.

Consent to participate: Informed consent was obtained from all individual participants included in the study.

Consent for publication: Informed consent was obtained from all individual participants included in the study.

Acknowledgments: To YARA Argentina and José Crespo for facilitating the fertilizer and help in the field with the nitrogen concentration assessment.

\section{References}

Aqueel MA, Leather SR (2012) Nitrogen fertiliser affects the functional response and prey consumption of Harmonia axyridis (Coleoptera: Coccinellidae) feeding on cereal aphids. Ann Appl Biol. https://doi.org/10.1111/j.1744-7348.2011.00514.x

Bernays EA, Chapman RF (1994) Host-plant selection by phytophagous insects. Chapman \& Hall, New York.

Blande JD, Pickett JA, Poppy GM (2007) A comparison of semiochemically mediated interactions involving specialist and generalist Brassica-feeding aphids and the braconid parasitoid Diaeretiella rapae. J Chem Ecol. https://doi.org/10.1007/s10886-007-9264-7

Carpane P, Laguna IG, Virla EG, Paradell SL, Murúa L, Giménez-Pecci MP (2006) Experimental transmission of Corn Stunt Spiroplasma present in different regions of Argentina. Maydica 51: 461-468.

Castro V, Rivera C, Isard SA, Gámez R, Fletcher J, Irwin ME (1992) The influence of weather and microclimate on Dalbulus maidis (Homoptera: Cicadellidae) flight activity and the incidence of diseases within maize and bean monocultures and bicultures in tropical America. Ann Appl Biol.

https://doi.org/10.1111/j.1744-7348.1992.tb03457.x

Chen Y, Schmelz EA, Wäckers F, Ruberson JR (2008) Cotton plant, Gossypium hirsutum L., defense in response to nitrogen fertilization. J Chem Ecol 34: 15531564.

Chen Y, Olson DM, Ruberson JR (2010) Effects of nitrogen fertilization on tritrophic interactions. Arthropod-Plant Interact. https://doi.org/10.1007/s11829-0109092-5

Ciampitti IA, Vyn TJ (2011) A comprehensive study of plant density consequences on nitrogen uptake dynamics of maize plants from vegetative to reproductive stages. Field Crops Res. https://doi.org/10.1016/j.fcr.2010.10.009

Loading [MathJax]/jax/output/CommonHTML/jax.js

Page 6/10 
Coll Aráoz MV, Jacobi VG, Fernández PC, Luft Albarracín E, Virla EG, Hill JG, Catalan CAN (2019) Volatiles mediate host-selection in the corn hoppers Dalbulus maidis (Hemiptera: Cicadellidae) and Peregrinus maidis (Hemiptera: Delphacidae). Bull Entomol Res. https://doi.org/10.1017/S000748531900004X

Coll Aráoz MV, Hill JG, Luft Albarracín E, Virla EG, Fernández PC (2020) Modern maize hybrids have lost volatile bottom-up and top-down control of Dalbulus maidis, a specialist herbivore. J Chem Ecol. https://doi.org/10.1007/s10886-020-01204-3.

Cook AG, Denno RF (1994) Planthopper/plant interactions: feeding behavior, plant nutrition, plant defense, and host plant specialization. In Denno RF, Perfect TJ (eds.) Planthoppers. Springer, Boston, pp 114-139.

Cook R M, Hubbard S F (1977) Adaptive searching strategies in insect parasites. J Anim Ecol. https://doi.org/10.2307/3950.

de Oliveira E, Magalhaes P, Gomide R, Vasconcelos C, Souza IR, Oliveira CM, Cruz I., Schaffert RE (2002) Growth and nutrition of mollicute infected maize. Plant Dis. https://doi.org/10.1094/PDIS.2002.86.9.945

de Oliveira E, Oliveira CM, Magalhães PC, Andrade CLT, Hogenhout S. (2005) Spiroplasma and phytoplasma infection reduce kernel production, and nutrient and water contents of several but not all maize cultivars. Maydica 50: 171-178.

de Oliveira E, Valiūnas D, Jović J, Bedendo I, Urbanavičienè L, de Oliveira C (2018) Occurrence and epidemiological aspects of Phytoplasmas in cereals. In Rao G, Bertaccini A, Fiore N, Liefting L (eds.) Phytoplasmas: plant pathogenic bacteria. Springer. pp. 67-89.

Deng S, Hiruki C (1991) Amplification of 16S rRNA genes from culturable and unculturable Mollicutes. J. Microbiol. Methods 14: 53-61.

Denno RF, Gratton C, Döbel H, Finke DL (2003) Predation risk affects relative strength of top-down and bottom-up impacts on insect herbivores. Ecology. https://doi.org/10.1890/0012-9658(2003)084[1032:PRARSO]2.0.CO;2

Douglas AE (2006) Phloem-sap feeding by animals: problems and solutions. J Exp Bot. https://doi.org/10.1093/jxb/erj067

Doyle JJ, Doyle JL (1990) Isolation of plant DNA from fresh tissue. Focus 12: 13-15.

EEAOC Agrometeorología. (2021). https://agromet.eeaoc.gob.ar/graficos.php?

estacn $=45$ anddesde $=26 \% 2 F 12 \% 2 F 2018$ andhasta=28\%2F03\%2F2019andopcion=1. Accessed January 31, 2021.

Evans GC (1972) The quantitative analysis of plant growth. Studies in Ecology. Vol. 1. 734 pp. Blackwell Sci. Publ., Oxford, UK.

Fallahpour F, Ghorbani R, Nassiri-Mahallati M, Hosseini M (2019) Plant fertilization helps plants to compensate for aphid damage, positively affects predator efficiency and improves canola yield. J Pest Sci. https://doi.org/10.1007/s10340-019-01129-1

Fertilizar (2020a) https://www.fertilizar.org.ar/subida/Estadistica/Evolucion\%20de\%20Consumo\%201990\%202013/EvolucionConsumo1990-2018.pdf Accessed 27 January 2021.

Fertilizar (2020b)

https://www.fertilizar.org.ar/subida/Estadistica/Consumo\%20de\%20Fertilizantes\%20en\%20todos\%20los\%20cultivos/Consumo\%20de\%20Fertilizantes\%20en

\%20los\%20cultivos\%202017.pdf- Accessed 27 January 2021.

Foley JA, Ramankutty N, et al. (2011) Solutions for a cultivated planet. Nature. https://doi.org/10.1038/nature10452.

Galdeano E, Guzmán FA, Fernández F, Conci LR (2013) Genetic diversity of 16Srlll group phytoplasmas in Argentina. predominance of subgroups 16Srlll-J and B and two new subgroups 16Srlll-W and X. Eur J Plant Pathol. https://doi.org/10.1007/s10658-013-0285-5

GBIF, The Global Biodiversity Information Facility (2021) Spiroplasma kunkelii. https://www.gbif.org/species/3226167. Accessed 06 August 2021.

Giménez Pecci MP, Carpane P, Carloni E, Nome C, Fiorona M, Laguna IG (2009) Técnicas empleadas en la identificación y caracterización de Spiroplasma kunkelii Withcomb et al. 1986 (reino Eubacteria, clase Mollicutes), In Laguna IG, Conci V, Rodríguez Pardina P, Truol G, Fiorona M, Di Feo L (eds.)

Procedimientos empleados en la identificación de organismos fitopatógenos. pp. 53-65 INTA Ediciones.

Giménez Pecci MP, De Rossi RL, et al. (2017) Enfermedades del maíz de siembra tardía causadas por virus, mollicutes y bacterias, In Borras L, Uhart S (eds,) El mismo maíz, un nuevo desafío: compendio primer Congreso de maíz tardío, pp. 128-145. Dow AgroSciences.

Gundersen D, Lee I (1996) Ultrasensitive by nested-PCR assays detection of phytoplasmas using two universal primer pairs. Phytopathol. Mediterranea 35: $144-151$.

Gunton RM, Pöyry J (2016) Scale-specific spatial density dependence in parasitoids: a multi-factor meta-analysis. Funct Ecol. https://doi.org/10.1111/13652435.12627

Han P, Desneux N, Becker C, Larbat R, Le Bot J, Adamowicz S, Zhang J, Lavoir AV (2019). Bottom-up effects of irrigation, fertilization and plant resistance on Tuta absoluta: implications for Integrated Pest Management. J Pest Sci 92: 1359-1370. https://doi.org/10.1007/s10340-018-1066-x

Loading [MathJax]/jax/output/CommonHTML/jax.js

Page $7 / 10$ 
Hruska A, Gómez Peralta M (1997) Maize response to corn leafhopper (Homoptera: Cicadellidae) infestation and achaparramiento disease. J Econ Entomol. https://doi.org/10.1093/jee/90.2.604

Jansson RK, Leibee GL, Sanchez CC, Lecrone SH (1991) Effect of nitrogen and foliar biomass on population parameter of cabbage insects. Entomol Exp Appl 61: 7-16.

Kalule T, Wright DJ (2002) Tritrophic interactions between cabbage cultivars with different resistance and fertilizer levels, cruciferous aphids and parasitoids under field conditions. Bull Entomol Res. https://doi.org/10.1079/BER2001134

Luft Albarracín EB, Paradell SL, Virla EG (2009) Cicadellidae (Hemiptera: Auchenorrhyncha) associated to maize crops in Argentina north-western, influence of the sowing date and phenology on their abundance and diversity. Maydica 53: 289-296.

Luft Albarracín EB, Triapitsyn SV, Virla EG (2017) Egg parasitoid complex of the corn leafhopper, Dalbulus maidis (De Long) (Hemiptera: Cicadellidae), in Argentina. Neotrop Entomol. https://doi.org/10.1007/s13744-017-0535-x

Moon DC, Rossi AM, Stiling P (2000) The effects of abiotically induced changes in host plant quality (and morphology) on a salt marsh planthopper and its parasitoid. Ecol Entomol. https://doi.org/10.1046/j.1365-2311.2000.00268.x

Moya-Raygoza G. (2020) Diversity and density-dependence relationship between hymenopteran egg parasitoids and the corn leafhopper (Hemiptera: Cicadellidae) in maize agroecosystem vs. teosinte wild habitat. Flo entomol. http://dx.doi.org/10.1653/024.103.0408,

Oliveira CM, Molina RMS, Albres RS, Lopes JRS (2002) Disseminação de molicutes do milho a longas distâncias por Dalbulus maidis (Hemiptera:

Cicadellidae). Fitopatol Bras. https://doi.org/10.1590/s0100-41582002000100015

Pereyra FX, Fernández DS (2018). North-western Argentina Soils. In Rubio G, Lavado R, Pereyra F. (eds.) The Soils of Argentina. pp. 123-134 Springer. https://doi.org/10.1007/978-3-319-76853-3_8

Pérez-Contreras T, Soler JJ (2004) Egg parasitoids select for large clutch sizes and covering layers in pine processionary moths (Thaumetopoea pityocampa). Ann. Zool. Fenn. 41: 587-597.

Ponder KL, Pritchard J, Harrington R, Bale JS (2000) Difficulties in location and acceptance of phloem sap combined with reduced concentration of phloem amino acids explain lowered performance of the aphid Rhopalosiphum padi on nitrogen deficient barley (Hordeum vulgare) seedlings. Entomol Exp Appl 97: 203-210.

Power AG (1989) Influence of plant spacing and nitrogen fertilization in maize on Dalbulus maidis (Homoptera: Cicadellidae), vector of Corn Stunt. Environ Entomol 18: 494-498.

Prestidge RA (1982) The influence of nitrogenous fertilizer on the grassland Auchenorryncha (Homoptera). J Appl Ecol 19: $735-749$.

Rossi AM, Strong DR (1991) Effects of host-plant nitrogen on the preference and performance of laboratory populations of Carneocephala floridiana (Homoptera: Cicadellidae). Environ Entomol 20: 1349-1355.

Santana Jr PA, Kumar L, Da Silva RS, Pereira JL, Picanço MC (2019) Assessing the impact of climate change on the worldwide distribution of Dalbulus maidis (DeLong) using MaxEnt. Pest Manag Sci. https://doi.org/10.1002/ps.5379

Schetino Bastos C, Cardoso Galvão JC, Coutinho Picanço M, Gomes Pereira PR, Cecon PR (2007) Nutrient content affecting Spodoptera frugiperda and Dalbulus maidis occurrence in corn. Insect Sci 14: 117-123.

Shehzad M, Gulzar A, Staley JT, Muhammed T (2020) The effects of drought stress and type of fertilizer on generalist and specialist herbivores and their natural enemies. Ann Appl Biol. https://doi.org/10.1111/aab.12654

Staley JT, Girling RD, Stewart-Jones A, Poppy GM, Leather SR, Wright DJ (2011) Organic and conventional fertilizer effects on a tritrophic interaction: parasitism, performance and preference of Cotesia vestalis. J Appl Entomol. https://doi.org/10.1111/j.1439-0418.2010.01604.x

Swank JC, Below FE, Lambert RJ, Hageman RH (1982) Interaction of carbon and nitrogen metabolism in the productivity of maize. Plant Physiol 70: 11851190.

Tariq M, Wright DJ, Rossiter JT, Staley JT (2012) Aphids in a changing world: testing the plant stress, plant vigour and pulsed stress hypotheses. Agric Forest Entomol. https://doi.org/10.1111/j.1461-9563.2011.00557.x

Tilman D, Cassman KG, Matson PA, Naylor R, Polasky S (2002) Agricultural sustainability and intensive production practices. Nature 418: $671-677$.

Todd JL, Phelan PL, Nault LR (1990) Interaction between visual and olfactory stimuli during host-finding by leafhopper, Dalbulus maidis (Homoptera: Cicadellidae). J Chem Ecol 16: 2121-2133.

Turlings TCJ, Benrey B (1998) Effects of plant metabolites on the behavior and development of parasitic wasps. Ecoscience 5: $321-333$.

Loading [MathJax]/jax/output/CommonHTML/jax.js $\quad$ D) Exploitation of herbivore-induced plant odors by host-seeking parasitic wasps. Science 250: $1251-1253$. 
Van Nieuwenhove GA, Frías EA, Virla EG (2016) Effects of temperature on the development, performance and fitness of the corn leafhopper Dalbulus maidis (DeLong) (Hemiptera: Cicadellidae): implications on its distribution under climate change. Agric Forest Entomol. https://doi.org/10.1111/afe.12118

Vinson SB (1998) The general host selection behavior of parasitoid hymenoptera and a comparison of initial strategies utilized by larvaphagous and oophagous species. Biol Control 11: 79-96.

Vinson SB (1999) Parasitoid manipulation as a plant defense strategy. Ann. Entomol. Soc. Am. 92: 812-828.

Virla EG, Casuso M, Frias E. (2010) A preliminary study on the effects of a transgenic corn event on the non-target pest Dalbulus maidis (Hemiptera: Cicadellidae). Crop Prot. https://doi.org/10.1016/j.cropro.2009.12.019

Virla EG, Logarzo G, Jones W, Triapitsyn S (2005) Biology of Gonatocerus tuberculifemur (Ogloblin) (Hymenoptera: Mymaridae), an egg parasitoid of the sharpshooter, Tapajosa rubromarginata (Hemiptera: Cicadellidae). Flo entomol 88: 67-71.

Virla EG, Díaz CG, Carpane P, Laguna IG, Ramallo JL, Gerónimo Gómez L, Giménez Pecci MP (2004) Estimación preliminar de la disminución en la producción de maíz causada por el “Corn Stunt Spiroplasma” (CSS) en Tucumán, Argentina. Bol San veg Plagas 30, 257-267.

Virla EG, Coll Aráoz MV, Luft Albarracín EB (2021) Estimation of direct damage to maize seedlings by the corn leafhopper, Dalbulus maidis (Hemiptera:

Cicadellidae), under different watering regimes. Bull Entomol Res. https://doi.org/10.1017/S0007485321000079

Walde SJ, Murdoch WW (1988) Spatial density dependence in parasitoids. Annu Rev Entomol 33: 441-466.

Waring GL, Cobb NS (1992) The impact of plant stress on herbivore population dynamics. In E Bernays (ed.) Insect-plant Interactions, Vol. 4. pp 168-226. CRC Press, Florida.

Weintraub P, Beanland L (2006) Insect vectors of phytoplasmas. Annu Rev Entomol. https://doi.org/10.1146/annurev.ento.51.110104.151039

\section{Tables}

Table 1: Phenological state of the crop, average densities of the vector (adults/plant) recorded 42 days after sowing, and characterization of the crop situation 54 days after sowing. Treatments: NO = control non-fertilized; N100 $=100 \mathrm{~kg}^{\star} \mathrm{ha}^{-1} ; \mathrm{N} 200=200 \mathrm{~kg}^{\star} \mathrm{ha}^{-1} ; \mathrm{N} 300=300 \mathrm{~kg}^{\star}$ ha ${ }^{-1}$. Different letters in the vector's density column indicate statistically significant differences (LSD test, $p<0.05$ ).

\begin{tabular}{|c|c|c|c|c|c|c|}
\hline & \multicolumn{2}{|c|}{42 days after sowing } & \multicolumn{2}{|c|}{54 days after sowing } & \multirow[b]{2}{*}{$\begin{array}{l}\text { plant height } \\
\text { range (meters) }\end{array}$} & \multirow[b]{2}{*}{$\begin{array}{l}\text { leaf relative } \\
\text { chlorophyll level }\end{array}$} \\
\hline & $\begin{array}{l}\text { phenological stage } \\
\text { of the plants }\end{array}$ & $\begin{array}{l}\text { vector density } \pm \\
\text { standard error }\end{array}$ & $\begin{array}{l}\% \text { of plants with male } \\
\text { inflorescence }\end{array}$ & $\begin{array}{l}\% \text { of plants with at } \\
\text { least one ear }\end{array}$ & & \\
\hline \multicolumn{7}{|c|}{ Treatments } \\
\hline NO & V7 & $0.067 \pm 0.021 a$ & 70 & 0 & $1.6-1.75$ & 257 \\
\hline N100 & V7-8 & $0.200 \pm 0.029 b$ & 90 & 0.5 & $1.7-1.95$ & 363 \\
\hline N200 & V7-8 & $0.320 \pm 0.049 b c$ & 100 & 15 & $1.8-2.00$ & 396 \\
\hline N300 & V8-9 & $0.373 \pm 0.016 c$ & 100 & 35 & $1.8-2.30$ & 538 \\
\hline
\end{tabular}

Table 2: Results (percentage) of the visual evaluation of symptoms for Spiroplasma kunkelii (CSS) and MBSP disease and the analytical determination of the pathogens for the different levels of $\mathrm{N}$ fertilization 89 days after sowing. Treatments: $\mathrm{N} 0=$ non-fertilized; $\mathrm{N} 100=100 \mathrm{~kg} \mathrm{ha}^{-1} ; \mathrm{N} 200=200 \mathrm{~kg}{ }^{\star} \mathrm{ha}{ }^{-1} ; \mathrm{N} 300=$ $300 \mathrm{~kg}^{*} \mathrm{ha}^{-1}$.

\begin{tabular}{|c|c|c|c|c|c|c|c|c|}
\hline \multicolumn{4}{|c|}{ Visual estimation } & \multicolumn{5}{|c|}{ Analytical determination } \\
\hline & & $\begin{array}{l}\text { plants with CSS } \\
\text { symptoms }\end{array}$ & $\begin{array}{l}\text { plants with MBSP } \\
\text { symptoms }\end{array}$ & $\begin{array}{l}\text { symptomatic } \\
\text { plants }\end{array}$ & & $\begin{array}{l}\text { positive for } \\
\text { CSS }\end{array}$ & $\begin{array}{l}\text { positive for } \\
\text { MBSP }\end{array}$ & $\begin{array}{l}\text { affected } \\
\text { plants }\end{array}$ \\
\hline Treatments & $\mathrm{n}$ & & & & $\mathrm{n}$ & & & \\
\hline NO & 100 & 15 & 27 & 42 & 40 & 35.0 & 25.0 & 60.0 \\
\hline N100 & 100 & 15 & 12 & 27 & 40 & 2.6 & 20.0 & 22.5 \\
\hline N200 & 100 & 3 & 15 & 18 & 40 & 20.0 & 10.5 & 25.0 \\
\hline N300 & 100 & 0 & 15 & 15 & 40 & 17.5 & 50.0 & 42.5 \\
\hline
\end{tabular}

\section{Figures}



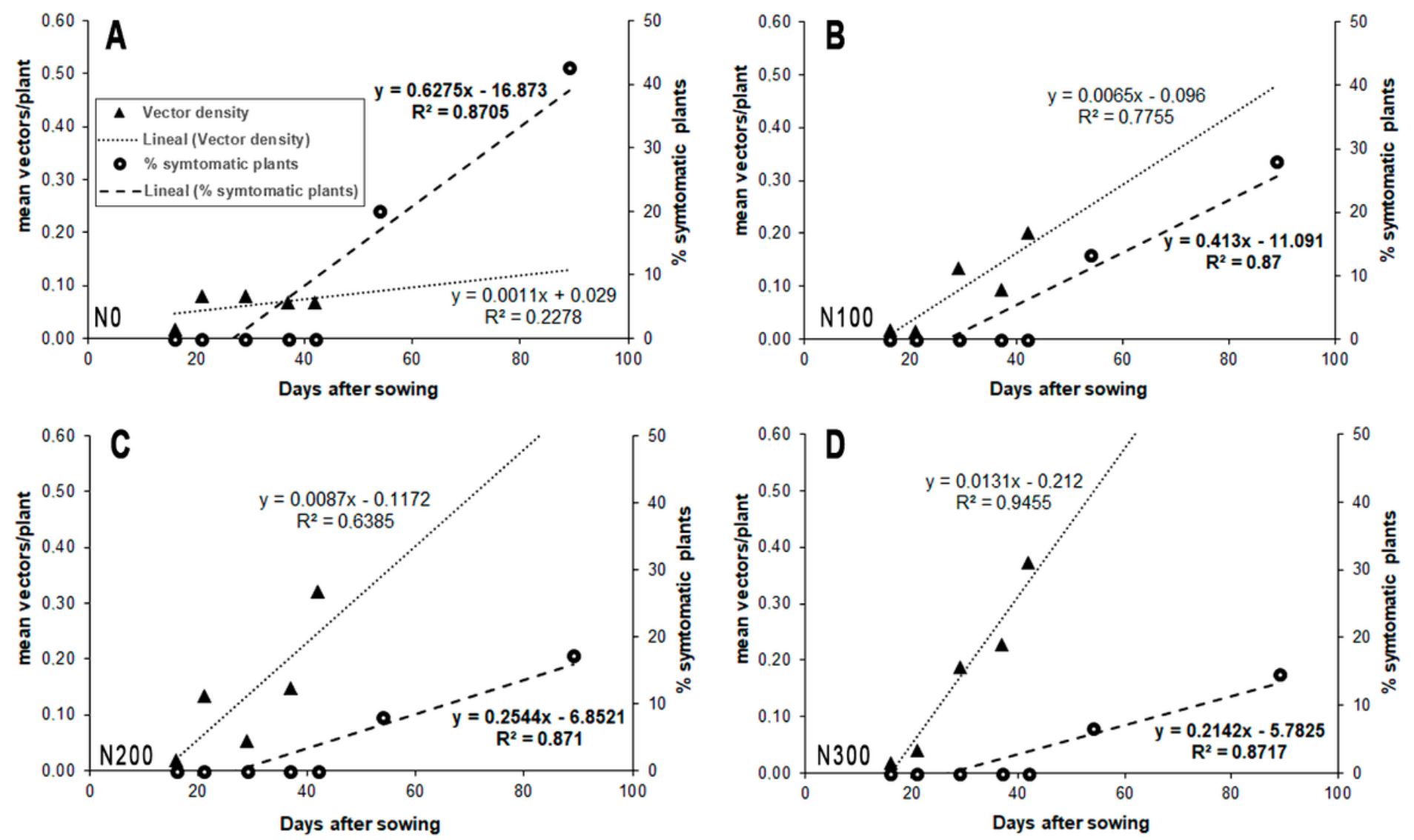

Figure 1

Evolution over time of the densities (mean adults/plant) of the corn leafhopper (Dalbulus maidis), and percentage of the symptomatic plants for corn stunting disease, in plots of maize with different levels of fertilization. The linear regressions between both variables and the time of maize development are presented (in days after sowing). Formulas represented in normal letters correspond to the regression between the vector densities and the development of the crop, and formulas with letters in bold correspond to the regression between \% of symptomatic plants and the time since the maize was sown. A: N0 = non-fertilized; $\mathrm{B}$ : $\mathrm{N} 100=100 \mathrm{~kg} \star \mathrm{ha}-1 ; \mathrm{C}: \mathrm{N} 200=200 \mathrm{~kg}$ ha-1; D: N300 = $300 \mathrm{~kg} \star \mathrm{ha}-1$.

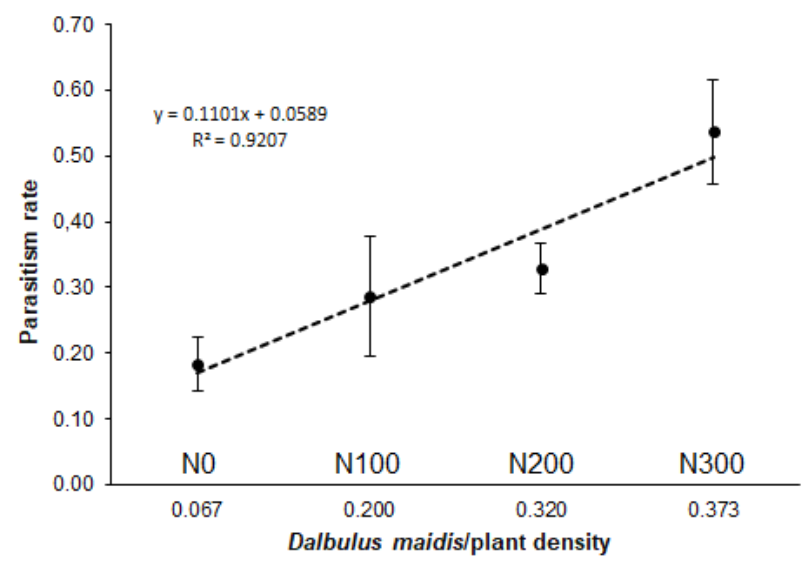

Figure 2

Relationship between natural parasitism rate and adult field density of D. maidis recorded for each treatment, 42 days after sowing (non-fertilized N0 = 0.067 ; $\mathrm{N} 100=0.200 ; \mathrm{N} 200=0.320 ; \mathrm{N} 300=0.373$. 